\title{
Utang Dan Pengakhiran Perjanjian Secara Sepihak (Studi Kasus Perjanjian Konsultan PT. Garuda dan PT. Magnus)
}

\author{
Awalia Noviyanti \\ Magister Ilmu Hukum Universitas Muhammadiyah Yogyakarta \\ Jl. Ring Road Barat, Tamantirto, Kasihan, Bantul, 55183 \\ 08562596230/awalianoviyanti30@gmail.com \\ Mukti Fajar Nur Dewata \\ Universitas Muhammadiyah Yogyakarta \\ Jl. Ring Road Barat, Tamantirto, Kasihan, Bantul, 55183 \\ 08122942781/mukti_fajarumy@yahoo.co.id
}

\begin{abstract}
This article aims to analyze the existence of the debt in reciprocal agreement between PT. Garuda and PT. Magnus, and about the termination of agreement which set aside article 1266 Civil Law unilaterally whether could cancel debt payment obligation or not. This research is normative research which observes the data that correlated to agreement, debt, act againts the law, and termination of agreement which set aside the article 1266 Civil Law. The approach of this article is statute approach which review the data that have correlation with law of agreement and termination of agreement, and case approach. It is the case of PT. Garuda and PT. Magnus. The data collection was done by library research that observing the data about law of agreement and termination of agreement. The result of research shows that there must be approval from each party in reciprocal agreement. Thus, the debt of PT. Garuda to PT. Magnus is the obligation that must be fulfilled due to PT. Magnus has worked maximally to complete its obligation. In other side, the termination of law which set aside article 1266 Civil Law is act againts the law, therefore the obligation to pay the debt must be done, in the reason of there is indemnification in act againts the law.
\end{abstract}

Keywords: Debt Agreement; Act Against the Law; Indonesian Civil Law

\section{ABSTRAK}

Penulisan ini bertujuan untuk mengetahui mengenai keberadaan utang yang terjadi dalam perjanjian timbal balik antara PT. Garuda dan PT. Magnus, serta mengenai pengakhiran perjanjian secara sepihak yang mengesampingkan Pasal 1266 KUHPerdata apakah dapat menggugurkan kewajiban pembayaran utang. Penelitian ini termasuk dalam jenis penelitian normatif yaitu dengan meneliti bahan pustaka yang berkaitan dengan perjanjian, utang, perbuatan melawan hukum, dan pengakhiran perjanjian yang mengesampingkan pasal 1266 KUHPerdata. 
Pendekatan yang digunakan dalam penelitian ini adalah pendekatan undang-undang dan regulasi yang bersangkut paut dengan hukum perjanjian dan pengakhiran perjanjian, serta menggunakan pendekatan kasus yang berkaitan dengan isi hukum perjanjian dan pengakhiran perjanjian yaitu kasus antara PT. Garuda Indonesia dengan PT. Magnus Indonesia. Pengumpulan data dilakukan dengan cara library research yaitu menggunakan bahan hukum yang mengkaji kasus hukum perjanjian dan pengakhiran perjanjian. Hasil penelitian ini menunjukkan bahwa dalam perjanjian timbal balik harus ada persetujuan dari masing-masing pihak. Dalam kasus ini utang PT. Garuda terhadap PT. Magnus merupakan kewajiban yang harus dipenuhi, karena PT. Magnus sudah mengusahakan pemenuhan kewajibannya secara maksimal. Kemudian pengakhiran perjanjian secara sepihak yang mengesampingkan Pasal 1266 KUHPerdata termasuk Perbuatan Melawan Hukum, jadi tidak dapat menggugurkan kewajiban pembayaran, karena dalam Perbuatan Melawan Hukum ada istilah ganti rugi.

Kata Kunci: Perjanjian utang; Perbuatan Melawan Hukum; KUHPerdata

\section{A. PENDAHULUAN}

Pada tahun 2000, PT. Magnus Indonesia dan PT. Garuda Indonesia menandatangani Perjanjian Konsultan (Consultant Agreement) dengan Nomor: DS/PERJ/DZ-3345/2000. PT. Garuda Indonesia adalah penerima jasa konsultasi dan PT. Magnus Indonesia sebagai penyedia jasa konsultasi sekaligus pelaksana. Dari perjanjian tersebut, seharusnya PT. Garuda melakukan pembayaran kepada PT. Magnus sebesar USD 794,939.00, dengan rincian utang pokok sebesar USD 612,806.00 dan bunga sebesar USD 160,133.00, serta biaya hukum sebesar USD 22,000.00, dengan perhitungan per tanggal 16 November 2005. (https://finance.detik.com/berita-ekonomi-bisnis/d-521183/garuda-indonesiadigugat-pailit, diunduh pada Kamis, 05 Januari 2017, pukul 22.06 WIB).

Namun pihak PT. Garuda melakukan Pengakhiran Perjanjian Konsultan dan Perjanjian Tambahan 1 yang berlaku efektif pada tanggal 14 November 2004 secara sepihak berdasarkan surat PT. Garuda pada tanggal 14 September 2004 dengan Nomor: Garuda/DZ2293/04, dengan dalih bahwa perjanjian konsultan dan perjanjian tambahan merupakan perjanjian yang sifatnya timbal balik. Menyikapi keadaan tersebut, PT. Magnus memohonkan pailit PT. Garuda ke Pengadilan Niaga namun Pengadilan Niaga menolak permohonan PT. Magnus, begitu juga saat diajukan kembali di Mahkamah Agung, PT. Magnus kembali menerima penolakan.

PT. Magnus tidak hendak mempermasalahkan pengakhiran secara sepihak atas perjanjian konsultan dan perjanjian tambahan 1 oleh PT. Garuda, namun PT. Magnus telah menagih PT. Garuda untuk membayar utangnya sebagaimana terbukti dari surat dengan nomor BTP/MI4002/RB01-VSA01/803/VIII/05, BTP/MI4002/RB01-VSA01/817/VIII/05， BTP/MI4002/RB01-VSA01/840/IX/05, 
Akan tetapi PT. Magnus bahkan tetap tak kunjung melunasi hingga tanggal permohonan pailit diajukan.

Merujuk pada Pasal 1266 KUHPerdata, syarat suatu perjanjian dapat dibatalkan oleh salah satu pihak adalah perjanjian harus timbal balik, terdapat wanprestasi, dan pembatalannya harus dimintakan kepada Pengadilan. Yang menurut Agus Yudha Hernoko dengan menekankan pada rumusan pemutusan "harus dimintakan kepada Pengadilan", kata "harus" pada ketentuan Pasal 1266 KUHPerdata ditafsirkan sebagai aturan yang bersifat memaksa ( $d$ wingend recht) dan karenanya tidak boleh dikesampingkan oleh para pihak melalui klausul perjanjian mereka (Hernoko 2010: 271).

Permasalahan dalam kasus tersebut muncul ketika PT. Magnus menyatakan bahwa PT. Garuda mempunyai utang meskipun PT. Garuda menyatakan sudah membayar utang tersebut. PT. Garuda memutuskan untuk mengakhiri perjanjian dengan dalih pekerjaan tidak sesuai isi perjanjian. PT. Magnus menempuh jalan hukum dengan memohonkan pailit untuk menanggapi keadaan tersebut. Permasalahan lain muncul ketika jalan yang ditempuh adalah dengan memohonkan pailit. Perjanjian dalam kasus ini adalah perjanjian timbal balik. Seharusnya dibuktikan terlebih dahulu sah atau tidaknya mengenai batalnya perjanjian. Sehingga jelas kedudukan perjanjian tersebut. Hal yang disoroti selanjutnya adalah pembatalan perjanjian yang dilakukan oleh PT. Garuda mengesampingkan Pasal 1266 KUHPerdata. Jika Pasal 1266 KUHperdata adalah suatu keharusan, maka konsekuensi dari mengesampingkan Pasal 1266 KUHPerdata harus siap diterima oleh PT. Garuda.

Menurut penulis, hal terpenting adalah harus dibuktikan keberadaan utang yang ditagihkan oleh PT. Magnus terhadap PT.Garuda. Sehingga nantinya jelas apakah PT. Garuda harus membayar utang tersebut atau tidak. Hal kedua yang harus dapat dijabarkan adalah tentang kewajiban membayar utang tersebut dikarenakan adanya pengesampingan Pasal 1266 KUHPerdata.

Meskipun penjelasan dalam Pasal 1266 KUHPerdata menggunakan istilah "pembatalan perjanjian", namun penulis akan menggunakan istilah "pengakhiran perjanjian” yang mengacu kepada kasus yang terjadi antara PT. Magnus dan PT. Garuda. Pengakhiran perjanjian dalam kasus ini mempunyai maksud yang sama dengan pembatalan perjanjian. Pengakhiran perjanjian dalam kasus ini disebabkan karena salah satu pihak merasa bahwa pihak lain wanprestasi yang memungkinkan debitur dituntut oleh kreditur. Pengertian tersebut sejalan dengan kalimat "andaikata salah satu pihak tidak memenuhi kewajibannya" dalam pasal 1266 KUHPerdata.

\section{B. METODE PENELITIAN}

Metode penelitian yang digunakan adalah metode penelitian hukum normatif. Yaitu dengan meletakkan hukum sebagai sebuah sistem bangunan norma. Sistem 
norma yang dimaksud adalah mengenai asas-asas, norma, kaidah dari peraturan perundang-undangan, putusan pengadilan, perjanjian serta doktrin (ajaran) (Dewata dan Yulianto, 2010: 12).

Pendekatan yang digunakan dalam penelitian ini adalah statute approach dan case approach. Bahan hukum yang digunakan untuk menganalisis adalah bahan hukum primer yaitu Kitab Undang-Undang Hukum Perdata, Putusan Mahkamah Agung Nomor 05K/N/2006, Jurnal Hukum tentang Analisis terhadap putusan pengadilan Niaga Atas Penolakan Permohonan Pernyataan Pailit yang Diajukan Oleh PT. Magnus Indonesia terhadap PT. Garuda Indonesia dan Putusan Niaga Nomor: 10/Pailit/2005/PN.Niaga/JKT.Pst. Sedangkan bahan hukum sekunder yaitu hasil riset atau penelitian terdahulu yang masih berkaitan dengan objek yang diteliti.

Teknik pengumpulan data yang dilakukan adalah dengan library research, baik bahan hukum primer maupun bahan hukum sekunder dan tersier dikumpulkan berdasarkan topik permasalahan yang telah dirumuskan dan diklasifikasikan menurut sumber dan hierarkinya untuk dikaji secara menyeluruh dan merupakan satu kesatuan (holistik) (Mahmudji, Sri, dan Soekanto, 2011: 21).

Analisis dalam penelitian ini menggunakan analisis data secara kualitatif. Analisis tersebut berdasarkan data yang memadai untuk menjawab permasalahan yang diajukan dalam penelitian ini.

\section{PEMBAHASAN HASIL PENELITIAN DAN ANALISIS}

\section{Keberadaan Utang PT. Garuda terhadap PT. Magnus}

Hal terpenting dalam kasus ini adalah keberadaan utang PT. Garuda yang dipermasalahkan oleh PT. Magnus. Utang tersebut adalah sebesar USD 794,939.00. Pembuktian adanya utang yang diklaim oleh PT. Magnus sangat penting, sehingga PT. Magnus mempunyai dasar yang pasti untuk menagih haknya.

Di bawah ini merupakan tabel rincian utang yang dimaksud oleh PT. Magnus:

Tabel 1. Rincian utang pada perjanjian awal yang terdapat dalam Putusan Mahkamah Agung Nomor: 05/K/N/2006

\begin{tabular}{|c|c|c|c|c|c|}
\hline No. & Tagihan & $\begin{array}{l}\text { Jenis } \\
\text { Pekerjaan }\end{array}$ & $\begin{array}{l}\text { Tanggal } \\
\text { Jatuh } \\
\text { Waktu }\end{array}$ & $\begin{array}{l}\text { Jumlah } \\
\text { Tagihan } \\
\text { (dalam USD) }\end{array}$ & $\begin{array}{l}\text { Bunga } \\
\text { (dalam } \\
\text { USD) }\end{array}$ \\
\hline 1. & $\begin{array}{l}\text { Surat Tagihan } \\
\text { (invoice) nomor } \\
\text { 08/2004/GRD- } \\
\text { ERP/07 }\end{array}$ & $\begin{array}{l}\text { Daftar yang } \\
\text { disetujui } \\
\text { dengan } \\
\text { permintaan } \\
\text { perubahan }\end{array}$ & $20 / 08 / 2004$ & $52,142.000$ & $15,770.00$ \\
\hline 2. & $\begin{array}{l}\text { Surat tagihan } \\
\text { (Invoice) nomor } \\
\text { 08/2004/GRD- }\end{array}$ & $\begin{array}{l}\text { Daftar yang } \\
\text { disetujui } \\
\text { dengan }\end{array}$ & $20 / 08 / 2004$ & $49,286.00$ & $14,906.00$ \\
\hline
\end{tabular}




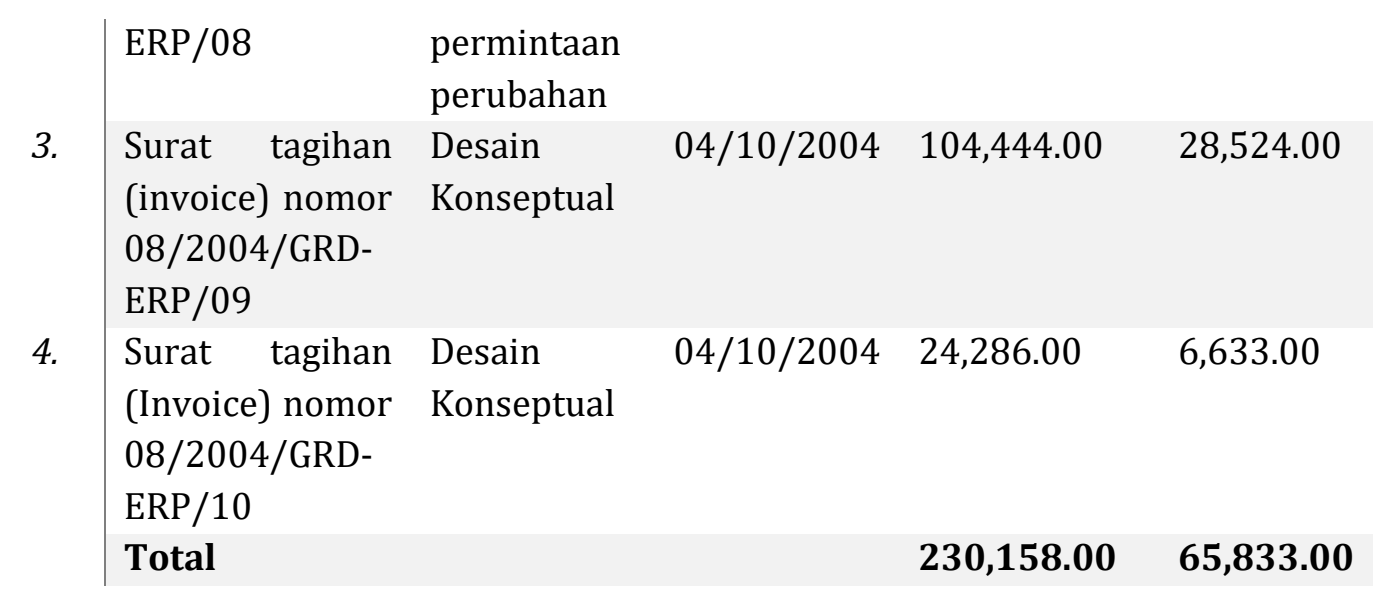

Tabel 2. Rincian utang pada perjanjian tambahan yang terdapat dalam Putusan Mahkamah Agung Nomor: 05/K/N/2006

\begin{tabular}{|c|c|c|c|c|}
\hline No. & Jenis Pekerjaan & $\begin{array}{l}\text { Tanggal } \\
\text { Jatuh Waktu }\end{array}$ & $\begin{array}{l}\text { Jumlah } \\
\text { Tagihan } \\
\text { (dalam USD) }\end{array}$ & $\begin{array}{l}\text { Bunga } \\
\text { (dalam USD) }\end{array}$ \\
\hline \multirow[t]{2}{*}{1.} & Konfirmasi & $14 / 11 / 2004$ & $97,222.000$ & $23,959.00$ \\
\hline & 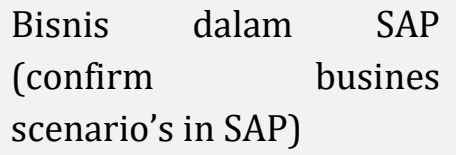 & & & \\
\hline 2. & $\begin{array}{l}\text { Penulisan/konfirmasi } \\
\text { program specs } \\
\text { (write/confrim } \\
\text { programing specs) }\end{array}$ & $14 / 11 / 2004$ & $50,000.00$ & $12,322.00$ \\
\hline 3. & Testing & $14 / 11 / 2004$ & $62,806.00$ & $15,478.00$ \\
\hline 4. & \begin{tabular}{lr} 
Skenario & \multicolumn{2}{c}{ konfigurasi } \\
bisnis dalam & SAP \\
(configure & busines \\
scenario's in SAP)
\end{tabular} & $14 / 11 / 2004$ & $22,699.00$ & $5,594.00$ \\
\hline 5. & $\begin{array}{ll}\begin{array}{l}\text { Konfirmasi } \\
\text { specs }\end{array} & \text { program } \\
\text { (confrim }\end{array}$ & $14 / 11 / 2004$ & $37,699.00$ & $9,291.00$ \\
\hline \multirow[t]{2}{*}{6.} & Testing & $14 / 11 / 2004$ & $112,222.00$ & $27,656.00$ \\
\hline & Total & & $382,648.00$ & $94,300.00$ \\
\hline
\end{tabular}

Pada dasarnya, PT. Garuda mempunyai kewajiban untuk memberikan tanggapan terhadap hasil pekerjaan PT. Magnus maksimal 12 hari kerja. Hal tersebut sesuai dengan pasal 6 perjanjian tambahan 1. Hal inilah yang menjadi dalil PT. Magnus untuk menagihkan haknya kepada PT. Garuda. 
"Failure to accept or respond to the final acceptance or a phase deliverable in 12 (twelve) working days conclusively means acceptance of the final acceptance or the phase deliverable"

(tidak diberikannya tanggapan untuk menerima penerimaan akhir atau fase penyerahan dalam jangka waktu 12 (dua belas) hari kerja akan berarti sebagai persetujuan atas penerimaan akhir atau fase pengiriman)

Selanjutnya, PT. Garuda juga menjelaskan bahwa pekerjaan yang dilakukan tidaklah sesuai dengan isi perjanjian. Dalam hal ini sebenarnya PT. Magnus mempunyai hak untuk memperbaiki pekerjaannya sehingga hasil akhir dari pekerjaan tersebut benar-benar sesuai dengan yang diinginkan PT. Garuda. Landasan dari adanya kesempatan untuk melakukan perbaikan pekerjaan adalah Pasal 16 perjanjian konsultan. Dalam pasal tersebut dijelaskan bahwa PT. Magnus diberi tambahan 30 hari untuk memperbaiki kesalahan dengan biaya dari PT. Magnus sendiri (Yuanita, 2006: 48).

"dalam hal berita acara penerimaan akhir tidak dipenuhi dalam jangka waktu 30 (tiga puluh) hari dari jadwal tanggal penyelesaian sebagaimana ditentukan dalam lampiran B, karena ketidakmampuan konsultan (pemohon kasasi) untuk memenuhi kewajibannya dalam perjanjian ini, konsultan (pemohon kasasi) dapat dianggap bersalah/lalai dan konsultan(pemohon kasasi) diberi tambahan 30 (tiga puluh) hari untuk memperbaiki kesalahan tersebut dan dalam hal kegagalan untuk memperbaikinya, maka sebuah perjanjian tambahan dengan Garuda (termohon kasasi) harus dibuat untuk memperbaiki kesalahan atas biayanya sendiri dengan mempergunakan usaha-usaha profesional terbaik atau perjanjian ini dapat diputuskan"

Akan tetapi PT. Garuda tetap tidak memberikan kesempatan tersebut kepada PT. Magnus untuk melakukan perbaikan. Bahkan PT. Garuda justru memutuskan untuk mengakhiri perjanjian konsultan dan perjanjian tambahan 1.

Agar dapat ditentukan apakah utang yang didalilkan oleh PT. Magnus memang benar adanya, maka perlu dianalisa tentang munculnya utang. Jika kita mengacu pada Pasal 1 angka 6 UU No. 37 Tahun 2004 tentang Kepailitan dan PKPU, untuk dapat dikategorikan sebagai utang, ada beberapa unsur yang harus terpenuhi. Pertama adalah utang yang merujuk kepada kewajiban hukum perdata. Kewajiban tersebut dapat diartikan sebagai memberikan sesuatu, berbuat sesuatu, atau tidak berbuat sesuatu, atau biasa kita sebut sebagai prestasi dalam suatu perjanjian. Prestasi dapat diartikan sebagai sesuatu yang diberikan, dijanjikan atau dilakukan secara timbal balik. Unsur yang kedua adalah kewajiban yang dapat dinyatakan dalam jumlah uang baik mata uang Indonesia maupun mata uang asing. Unsur yang ketiga adalah kewajiban dapat timbul secara langsung maupun yang akan timbul di kemudian hari (kontinjen). Keempat, kewajiban tersebut timbul karena perjanjian atau Undang-Undang. Kelima, kewajiban tersebut wajib dipenuhi. Dan yang terakhir 
adalah bila tidak dipenuhi, akan memberikan hak kepada kreditor untuk mendapatkan pemenuhannya dari harta kekayaan debitor (Sjahdeini dan Remy, 2002: 72).

Kasus PT. Magnus dan PT. Garuda dapat dianalisa dari penjelasan di atas. Pertama, masing-masing pihak harus memenuhi kewajibannya yang telah disepakati dalam perjanjian konsultan dan perjanjian tambahan I. Setiap pekerjaan yang sudah dilaksanakan oleh PT. Magnus dan mendapatkan persetujuan dalam jangka waktu 12 hari kerja, PT. Garuda mempunyai kewajiban untuk membayar pekerjaan tersebut. Dan ketika penyerahan hasil akhir tidak ditanggapi juga, setelah jangka waktu 12 hari kerja, penyerahan akhir tersebut selalu dianggap sudah disetujui oleh pihak PT. Garuda. Kedua, sah saja bagi PT. Magnus untuk menagihkan haknya dalam bentuk nilai tukar mata uang asing. Karena kewajiban tersebut dapat dinyatakan dalam jumlah uang baik mata uang Indonesia maupun mata uang asing. Ketiga, kewajiban yang timbul dari perjanjian konsultan adalah kewajiban para pihak untuk melakukan isi perjanjiannya. Sedangkan kewajiban yang akan datang dapat berupa kerugian maupun ketidaksesuaian hasil pekerjaan dengan yang sudah diperjanjikan. Jangka waktu 30 hari disepakati untuk diberikan kepada PT. Magnus jika memang perlu adanya perbaikan pekerjaan hingga hasil akhirnya benar sesuai dengan yang diingkan PT. Garuda. Keempat, kewajiban dalam kasus PT. Magnus dan PT. Garuda muncul karena adanya perjanjian konsultan. Dan terakhir, kewajiban yang sudah tertuang dalam perjanjian konsultan PT. Magnus dan PT. Garuda wajib dipenuhi.

PT. Garuda harus bertanggung jawab memenuhi kewajiban, karena sudah mendapatkan haknya, seperti dalam teori tradisional menurut Jimly Asshidiqie, ada dua jenis tanggung jawab: pertanggungjawaban berdasarkan kesalahan (based on fault) dan pertanggungjawaban mutlak (absolut responsibility) (Syaifudin dan Muhammad, 2012: 26).

Prinsip tanggung jawab mutlak sering diidentikkan dengan prinsip tanggung jawab absolut. Pada kasus ini PT. Garuda harus memenuhi kewajiban dengan bertanggung jawab karena akan tidak adil apabila PT. Magnus sudah memenuhi kewajibannya akan tetapi tidak mendapatkan haknya (Syaifudin dan Muhammad, 2012: 28).

Apabila PT. Garuda tetap tidak membayarkan kewajibannya, berupa utang yang menjadi hak PT. Magnus, maka tindakan PT. Garuda tersebut tidak mencerminkan keadilan, karena bisa disebut adil itu apabila keputusan yang diambil mengandung kebenaran, tidak berdasarkan kesewenang-wenangan, dapat dipertanggungjawabkan dan memperlakukan setiap orang pada kedudukan yang sama didepan hukum (Muhammad, 1980: 19)

Jika dilihat sesuai dengan pasal 6 perjanjian tambahan I, pasal 16 perjanjian konsultan, tagihan yang diajukan oleh PT. Magnus adalah sah dan berdasarkan pendapat para ahli yang menyatakan bahwa utang adalah kewajiban, maka dapat 
disimpulkan PT. Garuda mempunyai utang yang harus dibayarkan kepada PT. Magnus. Apabila PT. Garuda tetap tidak mau membayar kewajibannya, maka PT. Magnus dapat mengajukan gugatan ke Pengadilan Negeri. Sehingga putusan hakim dalam Pengadilan Negeri akan menjadi penentu terhadap kasus ini.

\section{Pembatalan perjanjian sepihak oleh PT. Garuda yang mengesampingkan pasal 1266 KUHPerdata tidak dapat menggugurkan kewajiban pembayaran.}

Pada tanggal 14 September 2004, PT. Garuda menyatakan untuk mengakhiri perjanjian konsultan dengan PT. Magnus. PT. Garuda juga menjelaskan belum seluruhnya menerima dengan baik perkerjaan yang telah diselesaikan PT. Magnus dengan alasan tidak sesuai dengan diperjanjikan, oleh karenanya tidak menandatangani penyerahan pekerjaan yang dilakukan oleh PT. Magnus. PT. Garuda juga mengakui telah beberapa kali melakukan pembayaran atas pekerjaan yang dilaksanakan oleh PT. Magnus (https://finance.detik.com/berita-ekonomi-bisnis/d524362/dirut-garuda-itu-masalah-simpel, diunduh pada Minggu, 08 Januari 2017, pukul 14.38 WIB)

Dari penjelasan tersebut, dapat disimpulkan bahwa perjanjian konsultan memang sudah terlaksana sebagian, akan tetapi isi dari perjanjian tersebut belumlah terlaksana secara keseluruhan. Jelas terlihat dari tagihan-tagihan yang dijadikan dasar PT. Magnus untuk mendapatkan haknya. Dalam tagihan tersebut, jenis pekerjaan yang dicantumkan tidak ada keterangan yang jelas menyatakan bahwa pekerjaan selesai dengan baik dan mendapatkan persetujuan dari PT. Garuda.

Suatu perjanjian yang dibuat oleh para pihak harus memenuhi persyaratan yang terdapat dalam pasal-pasal di KUHPerdata yang secara tegas menyatakan para pihak untuk mematuhinya (Suryono, 2014: 21). Karena perjanjian berlaku seperti Undang-Undang bagi mereka yang membuatnya. Terkait dengan hal tersebut, salah satu pasal yang terdapat dalam KUHPerdata adalah pasal mengenai ketentuan syarat batal yang diatur dalam pasal 1266 KUHPerdata. Pasal tersebut menyebutkan bahwa syarat agar suatu perjanjian dapat dibatalkan oleh salah satu pihak adalah perjanjian harus timbal balik, terdapat wanprestasi, dan pembatalannya harus dimintakan kepada hakim. Jika pembatalan tidak memenuhi syarat-syarat tersebut, maka dapat dikatakan pembatalan perjanjian secara sepihak tersebut melanggar Undang-Undang.

Rumusan kalimat yang terdapat dalam Pasal 1266 KUHPerdata pada ayat (1) menentukan bahwa syarat batal selalu dicantumkan dalam perjanjian, jika salah satu pihak tidak memenuhi kewajibannya. Selanjutnya Pasal 1266 ayat (2) menentukan "Dalam hal demikian perjanjian tidak batal demi hukum, tetapi pembatalan harus dimintakan kepada Pengadilan. Pada ayat (2) tersebut terdapat kata harus dimintakan kepada pengadilan. Kalimat ini mengindikasikan bahwa 
ketentuan Pasal 1266 ayat (2) KUHPerdata adalah hukum yang bersifat pemaksa dan karenanya tidak dapat dikesampingkan. Rumusan di atas dengan jelas mengatakan bahwa terjadi peristiwa yang dapat membatalkan perjanjian, tidak berarti bahwa perjanjian tersebut batal demi hukum tetapi harus dibatalkan oleh pengadilan melalui gugatan pembatalan perjanjian.

Menurut penulis, pengesampingan Pasal 1266 KUHPerdata merupakan wujud adanya itikad tidak baik bagi pihak yang memiliki posisi dominan, sebab ia akan mendahulukan keinginan dan kepentingannya. Pada dasarnya semua perbuatan hukum yang isi, maksud dan tujuannya bertentangan dengan ketertiban umum atau yang dilakukan melawan ketentuan perundang-undangan akan dinyatakan batal demi hukum. Dengan demikian klausul pengesampingan Pasal 1266 KUHPerdata disertai pencantuman klausul-klausul yang bertujuan untuk melaksanakan berlakunya klausul pengesampingan Pasal 1266 KUHPerdata dapat dinyatakan batal demi hukum karena bertentangan dengan Undang-Undang, sehingga ketentuan tersebut tidak memiliki daya ikat.

Pengakhiran perjanjian yang dilakukan oleh PT. Garuda bertentangan dengan Pasal 1266, dan ada kemungkinan perbuatan tersebut juga dikarenakan posisi PT. Garuda lebih dominan dari PT. Magnus. Sehingga pengakhiran perjanjian yang dilakukan oleh PT. Garuda termasuk dalam perbuatan melawan hukum.

Jika dilihat dari Pasal 1365 KUHPerdata, pengertian perbuatan melawan hukum adalah:

"tiap perbuatan melanggar hukum yang membawa kerugian kepada seseorang lain, mewajibkan orang yang karena salahnya menerbitkan kerugian itu mengganti kerugian tersebut"

Dari setiap tindakan melawan hukum mempunyai konsekuensi ganti rugi. Ganti rugi akibat dari perbuatan melawan hukum selain pengganti kerugian yang berwujud uang yang dijelaskan dalam Pasal 1243 sampai 1252 KUHPerdata, dapat diterapkan secara analogi, juga ganti rugi yang berwujud pemulihan dalam keadaan semula dan larangan untuk mengulangi perbuatannya lagi atau suatu prestasi yang bukan berupa uang untuk mengembalikan kerugian yang diderita. Ganti rugi karena perbuatan melawan hukum yang dijadikan acuan adalah mengembalikan pihak yang dirugikan kepada keadaan sebelum perbuatan melawan hukum terjadi, dan ganti rugi yang dapat dituntut adalah ganti rugi yang nyata diderita oleh pihak yang dirugikan. Satu sisi lain, teori analogi terhadap ganti rugi yang terjadi akibat perbuatan melawan hukum, pada umumnya ganti rugi selain kerugian yang ditimbulkan, juga harus membayar ganti rugi akibat keuntungan yang diharapkan diterima (winstderving).

Mengenai konsep ganti rugi karena perbuatan melawan hukum, dalam Kitab Undang-Undang Hukum Perdata tidak merincikan dengan jelas perhitungan ganti kerugian karena perbuatan melawan hukum, maka perhitungannya digunakan 
konsep ganti rugi karena wanprestasi secara analogis, terkecuali pada pasal-pasal yang dianggap tidak dapat digunakan pada konsep ganti kerugian karena perbuatan melawan hukum, yakni pasal 1247 dan 1250 KUHPerdata. Selain itu dalam ganti rugi karena perbuatan melawan hukum, menurut teori klasik yang dapat dituntut hanyalah ganti rugi yang nyata diderita oleh pihak yang dirugikan, akan tetapi teori ini tidak berlaku mutlak walaupun masih relevan untuk diterapkan. Namun hakim mempunyai batasan untuk dapat memutuskan dengan seadil-adilnya sebagaimana tercantum dalam pasal 178 ayat (3) HIR yang mengatakan bahwa hakim berwenang untuk menentukan berapa sepantasnya harus diganti kerugian.

\section{KESIMPULAN DAN SARAN}

Dari hasil pembahasan sebelumnya, dapat diambil kesimpulan bahwa utang PT. Garuda yang didalilkan oleh PT. Magnus merupakan kewajiban yang harus dipenuhi, meskipun perjanjian konsultan yang terjadi di antara mereka merupakan perjanjian timbal balik, akan tetapi PT. Magnus sudah memenuhi kewajibannya secara maksimal, jadi PT. Magnus harus mendapatkan haknya yang berupa pembayaran atas tagihan yang ada. Dan pengakhiran perjanjian sepihak yang mengesampingkan Pasal 1266 KUHPerdata merupakan Perbuatan Melawan Hukum dan tidak menggugurkan kewajiban pembayaran bahkan dalam Perbuatan Melawan Hukum dikenal istilah ganti rugi, karena dari Perbuatan Melawan Hukum tersebut ada kerugian yang nyata diderita dari suatu perbuatan melanggar hukum yang dilakukan.

Ketentuan Pasal 1266 KUHPerdata seharusnya lebih diperjelas lagi bahwa ketentuan tersebut bersifat memaksa, meskipun ketentuan Pasal ini terdapat dalam buku III BW yang bersifat terbuka dan pelengkap. Hal ini dimaksudkan agar tidak terjadi kerancuan mengenai penerapan hukum terkait dengan pengakhiran secara sepihak, sehingga para pihak dapat pula secara tegas untuk tidak mengesampingkan Pasal 1266 KUHPerdata dalam membuat perjanjian.

\section{DAFTAR PUSTAKA}

\section{A. Buku}

Hernoko, Agus Yudha (2008). Hukum Perjanjian Asas Proporsionalitas Dalam Kontrak Komersial. Yogyakarta: LaksBang Mediatama.

Mahmudji, Sri, dan Soerjono Soekanto (2011). Penelitian Hukum Normatif. Jakarta: Rajawali Pers.

Muhammad, Abdul Kadir (1980). Hukum Perjanjian. Bandung: Alumni.

Dewata, Mukti Fajar Nur dan Achmad, Yulianto (2010). Dualisme Penelitian Hukum Normatif dan Empiris. Yogyakarta: Pustaka Pelajar.

Sjahdeini dan Remy, Sutan (2002). Hukum Kepailitan Memahami Faillissementsverordening Juncto Undang-Undang No. 4 Tahun 1998. Jakarta: Pustaka Utama Grafiti. 
Suryono, Leli Joko (2014). Pokok-Pokok Hukum Perjanjian Indonesia. Yogyakarta: LP3M UMY.

Syaifudin, Muhammad (2012). Hukum Kontrak. Memahami Kontrak dalam Perspektif Filsafat Teori Dogmatik dan Praktik Hukum. Bandung: Mandar Maju.

\section{B. Jurnal}

Yuanita, Eva (2006) Analisis terhadap putusan pengadilan Niaga Atas Penolakan Permohonan Pernyataan Pailit yang Diajukan Oleh PT. Magnus Indonesia terhadap PT. Garuda Indonesia. Jurnal Hukum dan Pembangunan, 36(3).

\section{Putusan Pengadilan}

Putusan Mahkamah Agung Nomor: 05/K/N/2006

Putusan Pengadilan Niaga Jakarta Pusat Nomor: 10/Pailit/2005/PN.Niaga/Jkt.Pst.

\section{Internet}

http://finance.detik.com/berita-ekonomi-bisnis/521183/garuda-indonesiadigugat-pailit. (Diunduh pada Kamis, 05 Januari 2017, pukul 22.06 wib)

https://finance.detik.com/berita-ekonomi-bisnis/d-524362/dirut-garuda-itumasalah-simpel (Diunduh pada Minggu, 08 Januari 2017, pukul 14.38 wib) 